\title{
Changing Face of Performance Appraisal in Turkey: A Research within the Scope of International Studies
}

\author{
Burcin Cetin Karabat ${ }^{1} \&$ Suayyip Calis ${ }^{1}$ \\ ${ }^{1}$ Department of Human Resources Management, Faculty of Management, Sakarya University, Sakarya, Turkey \\ Correspondence: Burcin Cetin Karabat, Department of Human Resources Management, Faculty of Management, \\ Sakarya University, Sakarya, Turkey. Tel: 90-264-295-6292. E-mail: burcin@ sakarya.edu.tr
}

Received: August 21, 2014

Accepted: September 23, $2014 \quad$ Online Published: October 25, 2014

doi:10.5539/ibr.v7n11p117

URL: http://dx.doi.org/10.5539/ibr.v7n11p117

\begin{abstract}
In this work, we address the historical process that has been effective in shaping the current perception of performance appraisal in Turkey. We take into account cultural and legal factors affecting the performance appraisal. We study on three main surveys that provide an approach to performance appraisal systems (Arthur Andersen Survey, Cranfield Human Resource Management Survey, and Towers Watson Global Workforce Study) in Turkey. Finally, we make a general assessment, thus, suggestions for Turkish companies applying performance appraisal systems.
\end{abstract}

Keywords: performance appraisal, Turkey, cultural factors, legal factors, and international studies

\section{Introduction}

Performance appraisal, which is one of the most significant functions of HRM, is a process that is generally practiced by manager towards his subordinates and is designed with the aim of explaining employees' roles, aims, what is expected of them and performance successes (Snell \& Bohlander, 2007). Performance appraisal can be stated as evaluating the employees' current and/or past performances according to the performance standards. Performance appraisal always assumes that employees have the information on performance standards. Besides, it assumes that managers provide employees required incentives for feedback, development opportunities, making up for their shortages, and maintaining the average performance degree (Dessler, 2008). This case aims at developing the employee's performance. Thus, performance appraisal is accepted as the most important step of performance management systems.

Performance appraisal is not only a process in which employees' supports to the company and company's aims are assessed. It also bears the qualification of improving the organizational commitment of employees and motivating them. Along with this, within the performance appraisal process, there are many effective factors such as organizational culture, size of company, experiences of managers making performance appraisal.

Individual performance appraisal, which means employee's success degree according to the job or task he has to do, is an inevitable sub-system for a corporate performance management to be successful. While forming a general frame about the company, the corporation performance appraisal reports published by companies regularly do not directly reflect individual performance's success.

In books and articles, there are some studies on the current situation of performance appraisal in Turkey. However, while some of these studies deal performance appraisal along with other HRM functions (Aycan, 2001), others focus only on performance appraisal and analyze limited number of international researches related with the topic (Ozcelik, 2006; Aycan, 2008).

The main motivation of this work is to analyze the current situation of performance appraisal systems in Turkey. Thus, in our study, performance appraisal systems are discussed as a historical process, and as legal and cultural factors. The labor structure in Turkey and the results of three main global surveys that are about HRM applications have been analyzed from the performance appraisal system's point of view.

In the first part of this work, the historical process that has been effective in shaping the current perception of performance appraisal in Turkey is addressed. In the second part, cultural and legal factors affecting the performance appraisal have been mentioned. In the third part, the findings of three main surveys that provide an approach to performance appraisal systems (Arthur Andersen Survey, Cranfield Human Resource Management 
Survey, and Towers Watson Global Workforce Study) have been studied. Lastly, a general assessment was made and suggestions were made for the Turkish companies applying performance appraisal systems.

\section{Development of Performance Appraisal Systems in Turkey}

The development line that information on Human Resources Management (HRM), shows different features especially in some countries. The features that the subject has because of its root, dispersion dynamics towards foreign countries except UK and USA, and the similarities and differences that this dispersion has between practitioners and academicians have been a starting point for a lot of researches. There are some works on the dispersion of management information in Turkey as a country in the 'environment' position (Usdiken et al., 1998; Ozen, 2001; Usdiken \& Wasti, 2002). These works mainly present results about the content of the information endured to Turkey, the aims of actors who receives and produces the information and the technics they use. HRM, also, has a development process to be followed within this scope.

The HRM perception in Turkey has started to develop in accordance with legal regulations that came along especially with industry's booming. Yet, the concept's finding its meaning appears in the researches long before its application in working life, as it is in the other countries.

The term 'personnel management', which is the previous step of HRM, has been moved to Turkey in the earlier 1950s, with the starting of direct academic contacts with the USA. Concordantly, first publications containing the phrases 'personnel' or 'personnel management' began to be formed around the mid-1950s; however, the personnel management to be a discipline on its own took place around the endings of 1960s and the beginnings of 1970s (Usdiken \& Wasti, 2002, p. 2).

While personnel management was getting an independent discipline form, it developed an identity that reflects its 'principle', just like its emerging in the beginning of the era, in the USA. This identity brought forward the features of evaluating problems as a manager, emphasizing problem solving or applications instead of theorizing, and basing on the fact that related information is global (Usdiken \& Wasti, 2002, p. 8). All these elements have been effective in the current HRM perception to be formed.

Performance appraisal systems have started to develop, too, in parallel with the fast development of HRM since 1900s. The first examples of evaluating employees' performances systematically and formally appear in public utilities of the USA in the beginning of 1900s. During the following years, with measuring the performance by Taylor's work measurement applications, performance appraisal studies started to gain a form. The first formal performance appraisal application in Turkey was applied in public, Karabuk Iron and Steel Factory, in 1948 (Bingol, 1993, p. 21).

Towards the end of 1800s, a commission was founded within the Ministry of Internal Affairs in order to get some information about the personnel employed in the Ottoman Empire. Although this commission named 'Sicill-i Ahval' is one of the first applications of performance appraisal in Turkey, it is not accepted as a formal application for some researchers. The notebook that is named after the commission and that contains the behaviors of employees' during their working period has an official document value. It provides a central control in performing operations such as assignments, dismissals, and promotions (Gazel, 2007).

During the first years of performance appraisal, the results of evaluation were only used for adjusting the wages of the employees'. Yet, after 1930s, performance appraisal has been used for organizational effectiveness, and motivation providing that is related with increasing the employees' performances.

As continued to be applied in public institutions during the following years, performance appraisal has found an application area within some private sector constitutions especially after 1960s. The factors such as business science's gaining wide currency, changes in the market and workforce structures, modern management techniques' gaining importance and globalization have led the private sector to increase interest in performance appraisal.

One of the effective applications in forming the current performance appraisal perception is Labor Law that took effect in 2003. With this law, the results of performance appraisal system have gained formal document value in terminating labor contracts of employees' (Uyargil, 2013, p. 2). As a result of this, the applicants' and employers' interest in the matter has increased.

The studies taking performance appraisal systems in Turkey are in limited numbers in books and articles. Both books, essays and publications on performance management and performance appraisal (Aycan, 2001; Kula, 2005; Varma, 2008; Keles \& Aycak, 2001; Uyargil, 2013; Gul \& O'Connell, 2013) and longitudinal survey's data (e.g. Arthur Andersen Survey, Cranfield Human Resource Management Survey and Towers Watson Global 
Workforce Study) help us in understanding the situation of performance appraisal systems in Turkey.

\section{Key Factors Impacting PA in Turkey: Cultural and Legal Factors}

While the main strategies of HRM are being determined in a company, country's cultural and legal structure, and the general characteristics of individuals' attitudes and behaviors should all be taken into account. The social and organizational culture dominating Turkey is the mixture of "Western" and "Eastern" values (Aycan, 2001). With the effects of social and organizational cultures, companies face difficulties in adopting the new HRM trends.

According to Hofstede's research (1980), Turkey is among the countries that has a high level of power distance and uncertainty avoidance, feminine, and collectivist.

Local culture stands out in performance appraisal and reward applications. For example, in countries like the USA and UK where individualism level is high, performance appraisal and reward generally brings one specific person or group and ignores the support of others in this success. This is not very welcomed situation in collectivist cultures as Turkey. Thus, applications and developments of methods that will perform performance appraisal on basis of groups or companies will strengthen the team spirit.

In his research (1998), Davis has evaluated and analyzed the cultural formats of a number of countries, including Turkey that may affect performance appraisal systems. According to this, in performance appraisal, collectivist cultures should be approached in a different way than individualist cultures.

In Turkish culture, in which feminine values are more dominant, interpersonal relations are more emphasized than individual successes. Related to this, the importance given to relations and emotions is reflected the performance appraisal applications.

In societies with higher power distance value, social inequality and hierarchy are more acceptable. For this reason, employees' active participation in evaluation process is low. On the other hand, in Turkey where this value is high, companies are dependent, hierarchic; it is hard to reach upper levels, and an ideal manager is perceived as a father figure (Hofstede, 1980). In cultures with high power distance, superiors generally evaluate performance. As performance appraisal is generally a top-down process, it is really hard for companies with high power distance culture to let managers get evaluated by their inferiors. Thus, 360 degrees performance appraisal method may not be as attractive in high power distance cultures (Davis, 1998).

Societies avoiding high uncertainty are more apt to show sensuality compared to others. In such societies, individuals do not like changes and they avoid taking risks. According to Sargut (2001), a common Turkish application of 'life-long employment' is a result of tendency of avoiding uncertainty.

Davis (1998) points context culture as another notion that will affect the evaluation process. In low context cultures like the USA, the message to be given is clear. Feedback of performance appraisal is directly given to the employee, although it is negative. Besides, the employee has the right to criticize the evaluation. Turkey, on the other hand, has a high context culture. Within these kinds of cultures, the message to be given is not in the content but in the environment in which the message is given. Employer would not like the negative feedbacks to be told openly or to be reflected in the evaluation form.

Turkey is a fast changing society and its socio-cultural structure is in a constant change. Researches emphasize that, since Hofstede's studies, the individualist tendencies have risen in Turkey, but, still there is a structure that is highly collectivist (Goregenli, 1995; Aycan et al., 2000) and less hierarchical (Aycan et al., 2000).

The values of the cultural extend determined by Hofstede (2000) directs attitudes and behaviors of Turkish culture. However, the fact that there are many sub-cultural structures within the national culture should not be ignored.

The most important legal factor affecting performance appraisal applications in Turkey is the new Labour Act Law No 4857, which took effect in 2003. With this law that has took effect instead of the one used since 1971, making performance appraisal applications, although not directly, have become compulsory. This situation requires employers evaluate employees' performances systematically and objectively.

According to the new Turkish Labor Law (2003), in businesses having 30 or more employees, employer may cancel the contract of employment of indefinite duration of an employee with at least six months' experience. However, he has to lean this cancellation upon employer's inadequacy and behaviors; or a valid or fair reason rooted from company or job's requirements. One of those kind reasons rooted from employee's adequacy or inadequacy is performance-based cancellation.

There are two main valid reasons to cancel the work contract. These are listed in below: 
i) Working with less capacity than others doing the same job on average;

ii) Working with less performance than expected from mentioned qualifications.

Apart from these, the facts that performance appraisal system is appropriate to the company and workplace, that previously determined performance standards have been given in written notices to the employees and that performance criteria are concrete and measurable are significant. In another words, the company's performance appraisal system legally has a significant document value for both sides.

\section{Researches on Performance Appraisal Systems in Turkey and State of Performance Appraisal}

Performance evaluation for the first time in Turkey started in the public sector applications of interest into the private sector over time and became more widespread. Today, one of the classical performance appraisal methods (e.g. register records), which are based on the principles of confidentiality, is still used in the public sector. These applications are usually done by supervisors and such assessment documents are not transferred to employees.

In terms of private sector than the public sector, the situation is quite different. In Turkey, the private sector has led to carefully approach to performance appraisal systems due to the expansion of management science and modern management systems accurately and quickly implemented by the private sector (Source et al., 1998).

In this part of our study, three recent main studies have been analyzed in order to show the current state of performance appraisal in Turkey. These are Arthur Andersen Survey, Cranfield Human Resource Management Survey and Towers Watson Global Workforce Study. These three global surveys cover data collection for research and analysis of the results. Since they are performed by the global consulting companies and universities, their reliability is assumed to be high. In addition, continuous and long-term result of the work is one of the elements for improving reliability .

Arthur Andersen Survey and Cranfield Human Resource Management Survey have been performed within HRM functions. The starting point of Tower Watson Global Workforce Study, on the other hand, is the importance of sustainable commitment. General information on these three studies is summarized in Table 1. Besides, results for each study have been discussed in detail below.

Table 1. General information on Turkish performance appraisal systems' studies

\begin{tabular}{llll}
\hline & Arthur Andersen Survey & $\begin{array}{l}\text { Cranfield Human Resource } \\
\text { Management Survey }\end{array}$ & Towers Watson \\
\hline Manner of Application & Global & Global & Global \\
Years of Application & $1998, \mathbf{2 0 0 0}$ & $1992,1995,2000, \mathbf{2 0 0 5}$ & $\mathbf{2 0 1 2}$ \\
Number of Applicants & 307 companies & 171 companies & 750 employees \\
Frequency of Application & Seasonal & Seasonal & Instant \\
Elements of Research & All functions of HR & All functions of HR & Selection and performance, behavior, \\
Structure & & & commitment and productivity functions of HR \\
\hline
\end{tabular}

\subsection{Arthur Andersen Survey}

The first research to analyze HR functions among the companies operating in Turkey in detail was performed by Arthur Andersen Consulting Firm (1998, 2000). 109 companies from private sector were attended to the research in 1998. In the second step research in 2000, 307 surveys among the ones that had been sent to the first 750 companies of Istanbul Industry Chamber have been sent back replied. In our study, data from the year 2000 have been taken into notice as they are more updated. Data are from mainly finance, fmcg, automotive, textile, and health, IT, metal, durable goods, construction, holding, retail and media sectors. This study that had been performed by especially large scaled companies' attendances, cannot serve as a model to all Turkish firms (Aycan, 2008, p. 170).

According to Arthur Andersen Survey results (2000), performance appraisal system in Turkey is yet on the step of institutionalization. While appraising employees, criteria that reflect the whole success level of the company integrally should be handled. If only profit for the financial year is taken as the evaluation criteria, managers will focus on short-term profitability. Evaluation of employees does gain a meaning only after measureable success criteria such as market share; productivity and lead-time are used in the evaluation. When employees are 
evaluated before the company's performance is measured, the chances increase for failure to be rewarded.

Until 1980s, promoting and charging of employees had been done on basis of experience period in Turkey. On the other hand, recent performance-based evaluation studies have brought dynamism to the business world (Andersen, 2000).

According to the research data, while a formal performance appraisal system is applied in $81 \%$ of the attended companies, in $72 \%$, evaluation is performed with a standard form. It is seen that different applications have been used as evaluation criteria content. Most commonly, the same criteria were applied for organizational levels. For the organizational levels of employees from different management stages (e.g. blue-collars and manager candidate) same criteria were applied.

Standard applications are not encountered on performance criteria qualification in the business world. Main reason of this is the fact the performance appraisal in Turkey is yet on institutionalization stage. Consisting mainly of target-based evaluations and behavior-based criteria, combined evaluation systems are attracting more attention.

In the large part of all companies (93\%), performance appraisal is only conducted as a top-down process. In cultural context, this is an expected and acceptable situation in countries with high power distance, including Turkey (Pasa, et al., 2001; Aycan, 2008). The attendance ratio of the second managers to evaluation is $35 \%$.

Mutual assessment method is widely (43\%) used in dealing with performance appraisal results. Including feedback to the evaluating system supports the system in being more perfects. When the cultural structure is considered in Turkey, even the inferiors are asked their opinions about their superiors, it is seen that decisions are generally made individually. This situation is also observed in research results. It is detected that $11 \%$ of the participant companies' cannot have the chance to see the evaluation results. In this application, with the traces of 'registry' application of government, employee cannot see his deficiencies and cannot know his managers' concerns of himself.

Within the scope of this research, 29\% of the companies' think that the current system cannot meet the needs properly. The reason of this is the fact that performance appraisal systems of Turkey are in institutionalization stage and the searches for the best system still continues.

Most parts of performance appraisal applications are performed in individual-based form. With other words, every employee is evaluated one by one. Although the team concept has gained importance recently, research data shows that team based and project based evaluations are under $1 \%$.

The research reveals that the evaluations results carry the output value for a lot of HRM areas. According to this, evaluation results are not used for only one aim. In nearly half of the participant companies, results of performance evaluation are used in three HRM areas as career, wage and education. Binary combinations of these three follow this number. This result confirms the fact that $85 \%$ of the companies having career management system are conducting their current system in correlation with performance appraisal system. In systems conducted integrally, concrete results of the gains that employees acquire by career management can be obtained (Arthur Andersen Survey, 2000).

In $75 \%$ of the companies conducting performance appraisal, there is a rewarding system based on performance. The most common form of rewarding is the giving bonus and wage rise simultaneously. It is observed that performance-based rewarding is more commonly applied to the management group except blue-collars and manager candidates.

Although performance appraisal system is a developing area in private sector constitutions in Turkey, all results of Arthur Andersen Survey (2000) show that there appear some problems in the application stage of the system. Main reason of this is managers' and performance appraisal applicators' inability to avoid their prejudices, along with the cultural structure of Turkey.

\subsection{Cranfield Human Resource Management Survey}

The "Cranfield Project on International Strategic Human Resource Management" (Cranet) has the feature of being an international research web that applies frequent surveys on HRM areas in more than 40 countries. Among HRM policies and applications, the survey contains main areas such as selection and implantation, education and development, performance and career, wages and supplementary payments, employee relations and communication.

Including only European countries in the recent years, Cranet Survey, later, expanded its research web and gained a "global survey" feature by starting its applications in Japan, the USA, Israel or Australia. Set up in 1989 
by Cranfield Schoold of Management, The Cranfield Network on International Human Resource Management's primary target was to help reaching the information on the best applications and comparative performances especially in Europe and worldwide. Data was provided from Turkey for the researches of the years 1992, 1995, 2000 and 2005. In our study, data from 2005 are more widely used.

In Cranet Survey, as one of the longitudinal surveys' on HRM and performance appraisal in Turkey, most of the research data for Turkey has been gathered from private sector companies operating in different sectors. 1150 companies had been sent the survey form, and 171 survey, that had been sent replied, were taken into the research (Uyargil et al., 2006). According to the research results, in most of the participant companies, top-down evaluation process is used. This situation shows consistency with Arthur Andersen Survey. While in 2000, 79\% of participants had stated that only the first manager makes evaluation, this number has risen to $96 \%$ in research of 2005.

The rate of employees' participation to the evaluation process has risen over years (30\% in 1995 research, $42 \%$ in 2000 research, $77 \%$ in 2005 research). On the other hand, according to the previous research results, employees are getting evaluated by their inferiors has risen 4 times and reached $38 \%$. Yet, this number is quite below the expected one.

The results of 2005 research show that all evaluators' (first manager, second manager, employee's own, his coordinates, customers, and others) contribution to the performance appraisal process has risen compared to the previous research periods. The main reason for this may be seen as the Turkish Labor Law that took effect in 2003. This law, which accepts performance evaluation applications as a significant data for dismissals, has increased the importance that companies give to performance appraisal (Uyargil et al., 2006).

When the working groups within the scope of evaluation are analyzed, it is determined that $47 \%$ of Turkish companies evaluate managers, $52 \%$ specialists, $47 \%$ office employees, and $35 \%$ workers. These numbers are quite low compared to 1995 and 2000 researches whose results are close to each other (there is nearly 20-25\% decrease for each employee group). What the researches comment on this matter is not that participant Turkish companies are more interested in performance appraisal recently, but they are now paying more attention to HRM subjects compared to past years and giving more realistic replies.

Determining usage areas of performance appraisal system's results makes out the other part of Cranet Survey. According to the last research results, $82 \%$ of the participant companies stated that performance evaluation results are providing data for HR planning. There is not such data for the past years as this question was not included in the researches.

In the research of $2005,90 \%$ percent of the participants stated that they use performance evaluation results in analyzing the needs for education and development. This number was 53\% in 1995 and 2000. While in the previous researches, the usage rate of performance evaluation in career planning applications is around 40-50\%, in the last research this has doubled and reached to $87 \%$. This situation shows that Turkish companies are paying more attention to both career planning and performance evaluation recently. The data for usage of performance evaluation results in determining the wages is similar as the career planning data. Usage of the evaluation results in distribution of tasks has doubled and risen to $65 \%$. Usage areas of performance evaluation results have been discussed in Arthur Andersen Survey, as well. However, as in it more than one working areas evaluated all together, it is not possible to make a clear comparison between the two surveys.

\subsection{Towers Watson Workforce Study}

The most recent study on determining the situation of human resources in Turkey is 2012 Towers Watson Workforce Study. This research aims at leading the related companies in HRM area by analyzing different employee groups' selections, behaviors, performances, commitments and productivities. Compared to other researches, it is a recent and non-longitudinal study in Turkey.

While there are 32000 full-time employee working in medium or large size companies in 29 different companies are participating the research, there are 750 employees are included. Quarter of these are women. $26 \%$ of the participants are top and medium level managers, $19 \%$ junior managers and team leaders, $24 \%$ are specialists without any managerial responsibilities and white collar employees and support teams, $18 \%$ are blue-collar employees.

In Towers Watson Workforce Study, the importance of sustainable commitment was analyzed. In the research, sustainable commitment was placed on main factors of commitment, efficiency and activity. Here, commitment means the additional effort that the employee will make with his commitment to the company. Efficiency is the supply of required sources and tools for the employee to be able to work efficiently; activity is the existence of 
physical, social and emotional conditions to give energy to the employee.

According to this, 'sustainable commitment' concept gives clearer results for how to increase efficiency by measuring the efficiency and activity of individuals whose commitment is already ensured. Across the world, the factors affecting the sustainable employee commitment are; leadership, stress, work-life balance, and aims and targets of the company. In Turkey, on the other hand, communication becomes prominent as an efficient factor in performance management and company's aims and targets. According to the researches, employees in Turkey are committed to their companies but are not active and efficient. This situation roots from companies' deficiency of performance culture (Tower Watson 2012 Workforce Study).

In the report (2012), performance management has been described as one of the areas to be focused for sustainable commitment. Performance management's being understandable, performance and earning's being related, individuals' being responsible for their own performances and rewarding high performances are discussed as approaches and applications that employees give importance.

Another significant result of research results is the distrust of Turkish employees to performance and reward relationship. Only $28 \%$ of the participant employees believe that there is a relation between their performances and their earnings.

According to this, it is stated that, in the eye of employees, guaranteed wage keeps its importance among the reward components, and current variable wage programs are not sufficient in meeting employees' expectations and needs. Besides, employees stated that managers are not fair while forming performance and reward relation. Other points mentioned by the employees are that the company cannot successfully manage the performance management process and it cannot efficiently use technology in applying the process.

It is stated in the research that, with the effect of increase in economic stability and decrease in inflation levels, salary-based wage management leaves its place to performance-based variable wage method. Accordingly, it is clearly seen that many number of local and foreign companies operating in Turkey are now on the rails of performance culture intensification. As the follow up of Towers Watson Workforce Study (2012), Towers Watson Turkey Wage Research (2013) report focuses on the fact that there is the need of forming a performance culture that will make the system efficient in Turkey, by adding up all the factors that serve a function in actualizing the performance management.

\section{Overall Assessment}

That rewarding is made by experience and some subjective criteria in Turkey causes problems in every aspect of life, along with business world. In such environments, the moderate performance level of employees who do not push the limits of their abilities and potentials causes the slowdown of development pace in every aspect of life, along with the business life.

With the changes in the Labor Law, performance appraisal systems started to find a place in companies' agenda again. This increased companies' efforts of forming performance management systems. With the legal changes, companies started to observe employees' performances closely and they started a search of constituting systems for evaluation. This law requires the existence of a systematic performance evaluation systems in order the aims as developing fair wage systems, determining suitable performance criteria, and presenting objective and fair reasons of dismissals to be real. Thus, performance appraisal systems have become a significant and compulsory function for companies.

With foreign capital's entrance to the country, the increase in the number of multinational companies and each of these companies' bringing their own evaluation system to the country and harmonizing the systems all have fastened the development of performance evaluation system in Turkey.

In our study, researches on workforce and HRM applications including the performance appraisal systems in Turkey have been deeply analyzed. The research structure and results of Arthur Andersen Survey and Cranfield Human Resource Management Survey, which were carried out around the same times, are similar to each other. As distinct from these, Towers Watson Global Workforce Study aims at leading companies in HRM area and determining the development opportunities, instead of analyzing the current situation.

One of the most significant constraints in the researches is the usage of global and standard questionnaire forms. The legal, social and cultural differences between countries and regions may have caused some questions in the survey to be misunderstood or to be replied incorrectly.

Another constraint is rooted from the fact that none of the three studies mainly focus on the HR structure in Turkey. Studies are evaluated as the general frame and functions of HR. They are insufficient in reflecting the 
current picture of performance appraisal. The fact that there is no deep analysis on performance appraisal applications makes the analysis of the situation harder. An area research that only focuses on performance appraisal or performance related topics (motivation, efficiency, etc.) would be more useful in explaining performance appraisal's situation. Besides, comparing the current research results with other participant countries' results will give more clear information on the situation of performance appraisal in Turkey.

The lack of proper performance appraisal systems in the public sector of Turkey is mentioned in the works addressing the issue of performance appraisal systems in the literature. Not given enough attention to performance appraisal systems have led to problems in adequacy of public officials and quality of public services. Therefore, performance evaluation systems in the public sector should be reconsidered and features a contemporary appraisal system must be made. There is a need for developing performace appraisal standards, designing a performance appraisal system that can provide feedback to employees, providing training to evaluators, employees and management board, and making necessary regulatory changes.

Under the spotlight of surveys and literature analyses, Turkish companies can be suggested on performance management systems as below;

- Performance appraisal system should become a part of strategy management operating in the company. It mustn't be seen as a system that is applied in specific period and that gives marks to employees. It should be considered as a system that is coherent with the corporate objectives and that has a role in actualizing these objectives.

- Top management's support in presenting, applying and developing the evaluation system will increase the motivation of the employees.

- Performance appraisal system should be adopted by the employees, and it should be perceived as fair and objective. In order to achieve the objective of performance appraisal, more participation of employees should be ensured. By ensuring employees' participation in development of the system, the resistance to the system can be avoided. In addition, employees should be notified on the outcomes of performance appraisal and they should be provided proper feedback for their good and weaknesses. Thus, an organization will be positively affected.

- Performance appraisal systems should be taken into account when making a decision about an employee. This approach will increase motivation of employees as well as increase organizational success.

- Performance appraisal's being handled within corporate and environmental context and company's HR strategy, corporate culture, laws and technologic developments' scope will lead performance appraisal applications to success.

\section{References}

Andersen, A. (2000). 2001'e Dogru Insan Kaynaklari Arastirmasi. Istanbul: Sabah Yayincilik.

Arthur Andersen Consulting. (2000). Annual Survey of International Assignee Practices. New York: Author.

Aycan, Z. (2001). Human Resource Management in Turkey - Current Issues and Future Challenges. International Journal of Manpower, 22(3), 252-260. http://dx.doi.org/10.1108/01437720110398347

Aycan, Z., \& Yavuz, S. (2008). Performance Management in Turkey. In A. Varma, P. S. Budhwar, A. DeNisi (Eds.), Performance Management in Emerging Economies (pp. 168-180). London: Routledge.

Aycan, Z., Kanungo, R. N., Mendonca, M., Yu, K., Deller. J., Stahl, G., \& Khursid, A. (2000). Impact of Culture on Human Resource Management Practices: A Ten Country Comparison. Applied Psychology: An International Review, 49(1), 192-221. http://dx.doi.org/10.1111/1464-0597.00010

Bingol, S. (1993). Turkiye'de Is Degerlendirme Calismalarinin Incelenmesi. Ankara: Milli Produktivite Merkezi Yayinlari.

Davis, D. D. (1998). International Performance Measurement and Management. In J. W. Smither (Ed.), Performance Appraisal: State of The Art in Practice (pp. 95-131). San Francisco, CA: Jossey-Bass.

Dessler, G. (2008). Human Resource Management (11th ed.). NJ: Pearson Education, Inc.

Gazel, A. A. (2007). Sicill-i Ahval Defterlerine Gore Osmanli Donemi'nde Gorev Alan Anamurlu Memurlar. Ataturk Universitesi Turkiyat Arastirmalari Enstitusu Dergisi, 32, 203-213. http://dx.doi.org/10.9737/historyS528

Goregenli, M. (1995). Toplumumuzda Bireycilik-Toplulukculuk Egilimleri. Turk Psikoloji Dergisi, 11, 1-13. 
Gul, S. K., \& O'Connell, P. (2013). Police Performance Appraisals: A Comparative Perspective. Florida: CRC Press. http://dx.doi.org/10.1201/b13031

Kaynak. T., Adal, Z., Ataay, I., Uyargil, C., Sadullah, O., Acar, A. C., Ozcelik, O., Dundar, G., \& Uluhan, R. Insan Kaynaklari Yonetimi. Istanbul: Istanbul Universitesi İsletme Fakultesi Isletme Iktisadi Enstitusu.

Keles, S., \& Aycan, Z. (2011). The Relationship of Managerial Values and Assumptions with Performance Management in Turkey: Understanding within Culture Variability. The International Journal of Human Resource Management, 22(15), 3080-3096. http://dx.doi.org/10.1080/09585192.2011.599952

Kula, V. (2005). The Impact of the Roles, Structure and Process of Boards on Firm Performance: Evidence from Turkey. Corporate Governance: An International Review, 13(2), 265-276. http://dx.doi.org/10.1111/j.1467-8683.2005.00421.x

Labour Act of Turkey Law No. 4857.

Ozcelik, O. A. (2006). Turkiye ve ABD'deki Isletmelerde Insan Kaynaklari Departmanlarinin Stratejik Rolune Iliskin Karsilastirmali Bir Calisma. Yonetim Bilimleri Dergisi, 4(1), 69-97.

Ozen, S. (2000). Turk Yonetim Organizasyon Yazininda Yontem Sorunu: Kongre Bildirileri Uzerine Bir Inceleme. DAU Turizm Arastirmalari Dergisi, 1(1), 89-119.

Pasa, S. F., Kabasakal, H., \& Bodur, M. (2001). Society, Organizations, and Leadership in Turkey. Applied Psychology: An International Review, 50(4), 559-589. http://dx.doi.org/10.1111/1464-0597.00073

Sargut, A. S. (2001). Kulturler Arasi Farklilasma ve Yonetim (2nd ed.). Ankara: Imge Yayincilik.

Snell, S., \& Bohlander, G. (2007). Human Resource Management. OH: Thomson South-Western.

Towers Watson Consulting. (2012). Turkiye Isgucu Arastirmasi Raporu.

Towers Watson Consulting. (2013). Turkiye Ucret Arastirmasi Raporu.

Usdiken, B., \& Wasti, A. (2002). Turkiye'de Akademik Bir Inceleme Alani Olarak Personel veya Insan Kaynaklari Yonetimi, 1972-1999. Amme Idaresi Dergisi, 35(3), 1-37.

Usdiken, B., Selekler, N., \& Cetin, D. (1998). Turkiye'de Yonetim Yazinina Egemen Anlayisin Olusumu:Sevk ve Idare Dergisi Uzerine Bir Inceleme. Amme Idaresi Dergisi, 31(1), 57-87.

Uyargil, C. B., Sadullah, O. Z., Acar, A. C., Ozcelik, A. O., Dundar, G. I., \& Tuzuner, V. L. (2006). Cranfield Uluslararasi Stratejik Insan Kaynaklari Yonetimi Arastirmasi 2005 Turkiye Raporu.

\section{Copyrights}

Copyright for this article is retained by the author(s), with first publication rights granted to the journal.

This is an open-access article distributed under the terms and conditions of the Creative Commons Attribution license (http://creativecommons.org/licenses/by/3.0/). 